\title{
Henrik Ibsen’s Ghosts: A Critical Study of Hereditary Genetics
}

Amir Hossain*

Department of English, IBAIS University, Bangladesh

*Corresponding author: Amir Hossain, Department of English, IBAIS University, Bangladesh, Tel: +8801915908306; E-mail: amir.hossain.16578@gmail.com

Rec date: Dec 28, 2015; Acc date: Feb 10, 2016; Pub date: Feb 15, 2016

Copyright: ( 2016 Hossain A. This is an open-access article distributed under the terms of the Creative Commons Attribution License, which permits unrestricted use, distribution, and reproduction in any medium, provided the original author and source are credited.

\begin{abstract}
In this research-work, I would like to focus on the impact of "Hereditary Genetics" in Henrik Ibsen's Ghosts through creating the characters of Captain Alving, Mrs. Alving, and Oswald. It highlights why Captain Alving is sexually attracted to his maid-servant, Johanna. Due to an illicit relation between Captain Alving and Johanna, Regina was born in the Alving heritage. In the context of the scientific study of genetics as well as heredity, this article shows how Oswald is affected by a venereal disease, 'syphilis' due to a sexual relation with his own halfsister, Regina. For this purpose, the researcher applies the theory of 'heredity', 'genetics', and 'syphilis' in the light of genetic science with a view to investigating the mystery of sexual enjoyment between master and maid-servant, as well as brother and sister. In fact, this paper aims to look at hereditary guilt of the 20th century Scandinavian bourgeois society.
\end{abstract}

Keywords: Captain Alving; Mrs. Alving; Oswald; Hereditary genetics; Syphilis

\section{Introduction}

Henrik Ibsen's Ghosts is one of the most criticized plays in the history of English Literature. Ibsen wants to foster the gender discrimination through depicting the male and female characters in the light of the 19th century Norwegian Bourgeois customs and values. The playwright, as a self-conscious critic- cum -social reformer of his age, unveils the grim image of the filthy atmosphere. In his play, he wants to expose the hollowness and falsity of conventional morality, particularly the hollowness of conventional bourgeois marriage and family life. Ibsen shows the contemporary social issues: the hypocrisy of family life, the subordinate and subservient status of women and corruption in the familial, social, and communal affairs are considered unorthodox of his day. The main antagonists who are faced with conventions, hypocrisy, and sexual passion, and power, marriage of expedience, corrupted press, and vested interest are involved with hereditary guilt. In the play, Ghosts, Ibsen focuses the great stress upon the norms of hereditary guilt between father and son. He seriously studies the disordered human psychology and analyzes relentlessly the common relationship between the two siblings and husband and wife.

In this context, my research-work shows the sexual relationships between Captain Alving and Johanna as well as Oswald and Regina as reflected in Ibsen's Ghosts by applying the biological theory of hereditary genetics. It also aims to look at the mystery of hereditary guilt through the character-analysis of the protagonist, Mrs. Alving. Moreover, it focuses on the Freudian as well as Menckenian comments concerning hereditary disease with a view to unveiling the sexual relationships among male and female characters in the play, Ghosts.

\section{Theoretical Focus}

\section{Heredity}

Heredity is such a biological process through which particular characteristics are transmitted from parents to their children. The concept of heredity encompasses two seemingly paradoxical observations about organisms: the constancy of a species from generation to generation and the variation among individuals within a species. Constancy and variation are two aspects of the same coin, as becomes clear in the study of genetics. Both aspects of heredity can be explicated by genes, the functional units of heritable material that are found within all living cells. Every member of a species has a set of genes specific to that species. It is such a set of genes which provides the constancy of the species. Among individuals within a species, however, variations can occur in the form of each gene takes, providing the genetic basis for the fact that no two individuals have exactly the same traits.

Moreover, heredity is the passing on of characteristics from one generation to the next. It is the reason why offspring look like their parents. It also explains why cats always give birth to kittens and never puppies. The process of heredity occurs among all living things including animals, plants, bacteria, protists and fungi. The study of heredity is called genetics and scientists who study heredity are called geneticists. Through heredity, living things inherit traits from their parents. Traits are physical characteristics. You resemble your parents because you inherited your hair and skin color, nose shape, height, and other traits from them. In humans, eye color is an example of an inherited characteristic: an individual might inherit the brown-eye trait from one of the parents. Inherited traits are controlled by genes and the complete set of genes within an organism's genome is called its genotype [1].

Regarding heredity, professor Castle, in his recent book on "Heredity in Relation to Evolution and Animal Breeding," has defined heredity as "organic resemblance based on descent." The son resembles his father because he is a "chip off the old block." It would be still nearer the truth to say that the son resembles his father because they 
are both chips from the same block, since the actual characters of parents are never transmitted to their offspring in the same way that real estate or personal property is passed on from one generation to another. When the son is said to have his father's hair and his mother's complexion it does not mean that paternal baldness and a vanishing maternal complexion are the inevitable consequences.

Biological inheritance is more comparable to the handing down from father to son of some valuable patent right or manufacturing plant by means of which the son, in due course of time, may develop an independent fortune of his own, resembling in character and extent the parental fortune similarly derived although not identical with it. So, it comes about that "organic resemblance" between father and son, which appears between nephew and uncle or even more remote relatives, is due not to a direct entail of the characteristics in question, but to the fact that the characteristics are "based on descent" from a common source. In other words, a "hereditary character" of any kind is not an entity or unit which is handed down from generation to generation, but is rather a method of reaction of the organism to the constellation of external environmental factors under which the organism lives.

To unravel the golden threads of inheritance which have bound us all together in the past, as well as to learn how to weave upon the loom of the future, not only those old patterns in plants and animals and men which have already proven worthwhile, but also to create new organic designs of an excellence hitherto impossible or undreamed of, is the inspiring task before the geneticist today [1].

If the above mentioned biological theory of "Heredity" of Castle is applied to Ibsen's Play, Ghosts, then we will easily learn that the outcome of father's sinful and immoral act revisit his own son. Through analyzing the whole story, we will be able to prove hereditary guilt. It may be clearly expressed that father falls a tragic victim of syphilis due to an illicit relation with his maid-servant, and later his own son also fall victim of syphilis because of unknowingly making a physical relation with his own sister. At one stage, it is found that both father and son fall victim of syphilis; and both of them die prematurely. In this way, we will discuss the whole fact through applying the biological theory of "Hereditary Genetics" in the next section.

Moreover, now this scientific study highlights the venereal disease, namely "syphilis." At first, I will let you know the original theory of syphilis in a very brief way and then, it will expose how father and son have been affected by a venereal disease, 'syphilis' as well- constructed in Ibsen's play, Ghosts.

\section{Syphilis}

Syphilis was defined by Stokes as an infectious disease; due to Treponema pallidum; of great chronicity; systematic from the outset; capable of involving practically every structure of the body in its course; distinguished by florid manifestations on the one hand and years of completely asymptomatic latency on the other; able to stimulate many diseases in the fields of medicine and surgery; transmittable to offspring in man; transmittable to certain laboratory animals; and treatable to the point of presumptive cure [2].

There are two theories concerning the origin of syphilis. Some believe that it first appeared in the tropics as a primitive treponemal disease, usually transmitted by chance contact between individuals, especially children, and thus closely resembling the tropical treponematoses of the present day, such as yaws. The suggestion is that as the disease spread to more temperate climates, where more clothing was worn, and affected more advanced communities with better hygienic standards, transmission by sex contact became the usual method of the spread of the disease. The fact is that the treponemes of syphilis and yaws are morphologically indistinguishable, that the same blood test is positive in both diseases and both respond to the same treatment are points in favour of the theory of syphilis [3].

\section{Genetic and cultural effects in human behavior}

Human beings exhibit many important behavioral traits for which no candidate genes have been identified and for which the effects of individual genes are probably too small to detect with genetic linkage studies. For these traits, one measure of the overall importance of genetic factors is the broad-sense heritability, which is the ratio of the genotypic variance in the trait to the total phenotypic variance in the trait.

Estimating the heritability of any human behavioral trait requires that special attention be given to cultural transmission of non-genetic factors that potentially affect the behavior. These familial factors increase the resemblance between relatives, and, unless properly taken into account, they inflate the apparent genetic heritability. Most conventional genetic studies of human behavior are biased in which they include cultural transmission in the estimation of heritability, treating the situation as though cultural differences were genetic in origin [4].

If we apply the above mentioned theory of "Genetics and Cultural Effects in Human Behaviour" in Ibsen's Play, Ghosts, we will realize that Oswald has inherited his father, Captain Alving's behavioral traits. The effects of his father's genes are influenced by his own son. The cultural transmission of non-genetic factors affects their behaviours, for which these familial factors increase the resemblance between father and son. At the time of sexual relation with Johanna, the behaviours, which Captain Alving showed, Oswald, similarly, showed the same traits when he makes a sexual relation with Regina. In this way, this theory makes us indicate Genetic and Cultural Effects in the behaviours of both father and son.

\section{Sexual Relationship between Captain Alving and Johanna}

An analysis of the play, Ghosts supports Belsey's idea that patriarchy has imposed control over female sexuality, and has excluded women from state power and has made their position in the family "inconsistent" [5]. The other common theme that runs through the play is the silencing of female sexual individualism to guarantee patriarchy the power it desperately seeks. Power and sexuality [6] are inextricably connected in the play, Ghosts introduces a female character where Johanna is not appeared on the stage. She is pronounced through the dramatic dialogue between Pastor Manders and Mrs. Alving. Mrs. Alving, the protagonist, mentions about Johanna while disclosing her husband's immoral activities to Pastor Menders. Mrs. Alving states that her husband had a strong physical attraction towards women in the society. Johanna, working as a maid servant at the Alving Heritage, fell victim to sexual bondage and found herself in the clutches of Captain Alving. She tells Pastor Manders about her husband's unsocial behavior that she would live with Captain Alving despite his masochism. Mrs. Alving saw on the sly that he was greatly attracted towards Johanna. One day she observed the illicit sexual affair from the dining room. At that time she was working very nearly. Standing at the door, she heard her own servant whisper: "Stop 
it, Mr. Alving! Let me go!" [7] She felt very much pain on hearing their conversation. In this way, their physical relationship began to develop slowly. At one stage his physical union with Johanna got deepened. Johanna had no power to protest against her master where she was subjected to sexual exploitation. She did not get rid of his immoral deeds. Actually, Johanna has been shown as a disenfranchised woman of her age, and did not get any help from society, where she was confined to the cocoon. She had been totally victim of the aggressive nature of Captain Alving and inhumanly exploited and tormented through sexual violence and rape. We can realize about the sexual behavior and immoral deeds of Captain Alving through Johanna's voice: "Let me go, Engstrand! Stop it! I've been in service for three years with Chamberlain Alving at Rosenvold, and don't you forget it!" [7].

It is crystal apparent that Johanna had been acting both as a mistress and a maid- servant in the Alving Heritage. She never forgot that Captain Alving had made a chamberlain when she had been working for him. Captain Alving succeeded in having incestuous relationship with the maid servant. When she became pregnant, Mrs. Alving persuaded Engstrand to get married Johanna by giving him three hundred dollars due to social humiliation, and Engstrand also accepted the chance albeit it was a hideous crime from the social point of view. But Mrs. Alving conceals the sinful acts of her husband so that her only son Oswald cannot fall victim of dreadful circumstances. In this play, Johanna has been mentioned as a "degenerate" [7] character. This female character has been presented in front of us with a view to focusing on the inner faults and vices of Mr. Alving's personality. In this way, we can be able to realize the forbidden attractions between the master and the maid servant through Ibsen's creating the off stage scenes and characters [8].

The following speeches of Catharine Mackinnon are also very pertinent to this paper. Mackinnon argues that sexuality constitutes gender. In other words, there is no alienation between the concepts of gender and sexuality; male and female do not exist outside of the eroticization of dominance and subordination. As Mackinnon (1982) comments as follows:

Sexuality, then, is a form of power. Gender, as socially constructed embodies it, not the reverse. Women and men are divided by gender, made into the sexes as we know them, by the social requirements of heterosexuality, which institutionalize male sexual dominance and female sexual submission. If this is true, sexuality is the linchpin of gender inequality [9].

If we consider the fatal circumstances of poor Johanna, we can acknowledge that this is a powerful argument. Sexuality is viewed as a primary form of oppression of women, or just one form of oppression among others. Thus, the sexual dominance of Captain Alving and the sexual submission of Johanna may be applied by the judgments of Mackinnon. It is, however, agreed by many feminists that women need far greater control over their own bodies and their sexuality. Moreover, Ibsen has unveiled the conflict and struggle for existence of his contemporary feminism. These types of characters, in the field of literature, have possessed a remarkable place in his major prose plays, where the playwright has emphasized on female oppressions and entangled relationships of different thread through impacting upon an identity of genuflected livelihood.

In the play, Ghosts, we do not see Captain Alving on the stage. But, we can realize about his nature and behavior from the dialogue of Mrs. Alving while commenting his immoral and sinful character with
Pastor Manders. Mrs. Alving's view of her husband can be explained also by following Belsey's idea that the manifestation of female sexuality is considered as a threat to the masculine social order. Certainly, Ibsen wants to show Captain Alving as a careless person, with no great love for his family. He showed no concern for his wife. Though "society would consider him as one of its pillars"; he is, in fact, "a dissolute" [7], a drunkard, a libertine and a rakish. Even he did not hesitate to seduce his maid-servant. He was a violator of social law and order. He had no shame of the family. He was a masochistic type of person. From social point of view, we sense that no sensible being can tolerate such types of immoral activities and forbidden attractions of Captain Alving in any civilized manner. In fact, Ibsen has exposed the social realities of day's custom and manner. Through the character of Mr. Alving, Ibsen has exposed the 19th century Scandinavian life structure, culture, community, and society. If anyone attends to the deeper ideas and thoughts of his filthy personality, I think, he would, undoubtedly, realize the inner truth why Captain Alving had got involved into the sexual activities with the maid servant. Then the mystery might be conceptualized in the inner psychology. The physical demand what Captain Alving had expected from Mrs. Alving was not satisfactory. Actually, his wife failed to fulfill the physical and mental attraction of her husband. Therefore, we may sense that such types of unexpected incidence might happen in any human society. Even though Captain Alving is condemned from the social and moral perspective, but I think, Mrs. Alving is no less responsible for the sexual relationship between Captain Alving and Johanna. In accordance with the balance of Justice, both husband and wife may be equally punished. Regarding the character of Captain Alving, Mrs. Alving also tells Pastor Manders:

I had to fight, day after day, to keep it secret. After Oswald was born, I thought, things became a little better with Alving. But, it didn't last long. And, now I had to fight a double battle, fight with all my strength to prevent anyone knowing what kind of a man my child's father was. And, you know what a winning personality Alving had. No one could believe anything but good of him. He was one of those people whose reputations remain untarnished by the way they live [7].

In this way Captain Alving's dirty personality is revealed through Mrs. Alving's dialogue. We can assume that Captain Alving is the embodiment of the 19th century Norwegian bourgeois patriarchy through whom Ibsen has unveiled the corrupted aspects of hereditary disease, syphilis. In fact, Captain Alving faces a victim of venereal disease, syphilis due to making a sexual relation with his maid-servant, Johanna for which he has to lose his life prematurely [8].

In the play, Ghosts Ibsen has linked the theme of "the Joy of Life" [7] with that of incestuous relationship between men and women of his age. In fact, the playwright has hinted at the male domination and female bondage of the society and an illegitimate birth through hereditary guilt. He does not attack mankind, but, the behavior of man lacks in reason and morality. Man often wears the cloth of reason and morality but, when he gives up that garb, he is nothing but a brute. Thus, the researcher sheds a new light over brutality, immorality, irrationality, hypocrisy and above all, sexual oppression and bondage in the light of hereditary genetics.

\section{Sexual Relationship between Oswald and Regina}

This research-work throws light on Regina's physical glamour as well as a profound sexual relationship between half-brother and halfsister. In the play, Ghosts Regina is minor female character. Although 
she seems to be trivial in comparison with the main female character, Mrs. Alving, but Regina is not at all negligible under the over-all consideration of many critics and scholars. The complex sexual relationship in the play, Ghosts can be seen in the incidents through getting involved Oswald and Regina. In the first part of Act I, We find Regina who seems to be around 23 years old, appear as a physically and psychologically strong young woman, determined and optimistic, high ambitious, and convinces that she has a stay in Paris ahead together with Oswald, the son in the Alving Heritage where she herself has been brought up [10]. In fact, she is an illegitimate daughter of Captain Alving. The Captain had a sexual relationship with a maid servant of his wife, and this Regina is the product of illicit affair. But, she does not know her own mysterious truth. She knows that she is the daughter of lazy, inactive, inferior minded carpenter Engstrand, and whom she scorns through words like. "Alright, now, get out of here. I'm not going to stand around, having rendezvous with you" [7]. In the first act of the play, Mrs. Alving sees that Regina is very much attracted towards Oswald. She is not at all hesitated to connive at him. Mrs. Alving sees the presence of both of them in the dining room. Oswald tries to grasp Regina. From the dining room, she hears the crash of a chair being knocked over. At the same time, Regina says sharply, but keeping her low voice: "Oswald! Are you mad? Let me go!" [7] Regina starts distraughtly at the half open door. Oswald coughs, and begins to hum. Mrs. Alving thrills in fear. She observes the prenatal existence of her own husband's and Regina's mother in the relationship between Oswald and Regina. At one stage, Mrs. Alving supports this profound sexual relationship by breaking all sorts of conventional reformation. Oswald feels that his salvation lies in Regina's physical glamour which is full of vitality and joy of life. He wants to go away from home taking Regina with him. He would like to work again with a new lease of life and fresh energy painting: "Light and sunshine and holiday - and shining, contented faces" [7]. He is afraid of remaining at home with his mother, where all his instincts should be warped into ugliness. But, when Regina understands her true relation with Oswald, She decides to leave the Alving Heritage. She, apparently, declares that there can never be anything serious between them. She is not going to stay out at the Alving's home in the country and wear herself out looking after invalids. Regina feels the awakening of joy of life in her, but, it is the joy of her mother's kind, a sullied joy. The values which are deeply rooted for so long in her soft heart, is now devastated like a turbulent storm of heredity. In this regard, Regina says: "If Oswald takes after his father, I should not be surprised but what I'll take after my mother" [7]. She decides to go to the "Sailor's Home" a euphemism for a brothel. Obviously, Ibsen seems to suggest that Regina has no option but to succumb to the combined forces of hypocritical, moral codes and heredity which act as her fate. "What must be must be," [7] what she says in a bitter-sweet resigned speech. We see that Regina's struggle for freedom from sexual bondage does not succeed in any true sense. Ibsen wants to hint at the shining and existing unsubstantial false trammels, social values and the impact of heredity jointly on which Regina's fate is controlled. The physical relationship between Regina and Oswald may be supported because they did not know their secret siblings. In fact, Oswald wants to get rid of his venereal attack through Regina's love and mental satisfaction is contained in her love, affection and physical relation. But in the long run, Oswald does not save himself from hereditary guilt. Regina is a victim of cruel fate. For her livelihood, she is compelled to follow her mother's business. Thus, the researcher focuses on the sexual relationship between Oswald and Regina by applying the biological theory of hereditary genetics as stated above [11].

\section{Mrs. Alving's Struggle Against "Hereditary Guilt”}

Mrs. Alving is a protagonist in the play, Ghosts. Through this character, Ibsen wants to show the unexpected truth of the bourgeois society of his age. Mrs. Alving is the round character. Through Mrs. Alving, the research-work will investigate the mystery of the hereditary guilt between father and son, where I will try show how hereditary genetics dominated on father as well as son through a venereal disease, "syphilis." Due to this venereal disease, both of them fall victim of a tragic downfall.

Mrs. Alving locks up all the repressive mental suppressions and conflicts. Instead of getting rid of the exorcism. She, following the advice of Pastor Manders, the personification of false, conventional stupid respectability, sends her son Oswald to school away from him, and assiduously nurtures the myth of her husband as a noble and worthy figure, presumably suffering all the while in silence bitter agonies of shame and frustration. But now, on her husband's death, she wants to free herself of hereditary guilt by all means. She wants to set up an orphanage with the Captain's money, on the one hand to pacify any rumors, there may be of her husband's immoral, sinful life. Mrs. Alving sees the stranglehold of her "dissolute" husband on herself even after his death in Oswald's preference for the unconventional joys of life. However, she gets rid of her superstitions regarding duty and decency and braces herself to make a new beginning only to be crushed by the terrible denouement that her son has contracted venereal disease "syphilis" as an inheritance from his father. Mrs. Alving's growth and development constitutes one of the strongest appeals of hereditary guilt. We know her identity when she is a middle aged woman; her heart battered and lacerated, tries desperately to face the truth without any false trammels. She discovers in less than a year of married life that her husband was a rake and a libertine. She, then, fled from him, took refuge with the clergyman and intimate family friend, Pastor Manders and refuted to go back to Captain Alving. But, the Pastor sent her back to her husband, telling her, “... a wife is not to be her husband's judge. It is your duty to bear with humility the cross which a Higher Power has, for your own good, laid upon you" [7]. Mrs. Alving goes back and keeps home for about two decades for a "dissolute" husband, persuaded by Manders to shoulder the yoke, of what he calls Duty and Obligation. But, now twenty years later, she confesses to Manders that her whole soul has rebelled against that as something "loathsome." Her appreciation of the role of joy in one's life sets her apart from the stereotyped character of a harassed, duped wife. Mrs. Alving's quest for life and joy adds an extra dimension to her character and lifts her from merely being a vehicle for the debunking of traditional values. From the above point of view, we sense that Captain Alving had imposed power and domination on Johanna, and had excluded her from social right and responsibility. Finding no other alternative way, Johanna had been compelled to follow the path of prostitution. Ibsen wants to show sexual bondage and subordination of his age through portraying the two minor characters, includingJohanna and Regina [12].

In Act II, Mrs. Alving tells Manders that she must work her way out to freedom. She regrets her past cowardice and would like to be free of her "superstitions awe for Duty and Decency." And, here at this point Ibsen links the theme of "the joy of life" with the incestuous relationship male and female. Mrs. Alving sees that Oswald is attracted by Regina, who, unbeknown to him, happens to be his half-sister. She feels that joy is an important creed of life and she longs to say to her son: "Marry her, or make what arrangement you please, only let us have nothing understand about it" [7]. Mrs. Alving has traveled a long 
way mentally from her earlier stage of blindly and docilely adhering to hypocritical canons of conventional morality, but in actual life, she is still unable to say those words to her son. She is still "pitiful coward", and she, unerringly, diagnoses the reason for her cowardliness. She is timid because she cannot get rid of hereditary guilt that haunts her mind. And, in one of the most moving, important, theoretically effective and revealing speeches of the play. Mrs. Alving elaborates in answer to a query of Pastor Manders:

Ghosts! When I hear Regina and Oswald in there, I seem to see Ghosts before me. I almost think, we're all of us Ghosts, Pastor Manders. It is not only what we have inherited from our father and mother that 'walk' in us. It's all sorts of dead ideas, and lifeless old beliefs, but they cling to us all the same; and we can't get rid of them. Whenever I take up a newspaper, I seem to see Ghosts gliding between the lines. There must be Ghosts all the country over, as thick as the sand of the sea. And, then, we are one and all, so pitifully afraid of the light [7].

Mrs. Alving sees the hereditary guilt too clearly when she discovers that though she does not want Oswald to inherit a single penny from the purchase money Captain Alving had paid for her, all her sacrifice does not save Oswald from the poisoned heritage of his father. She learns soon enough that her beloved boy has inherited a terrible disease from his father, as a result of which he will never again be able to work. She also finds out that, for all her freedom, she has remained in the clutches of hereditary guilt, and that she has fostered in Oswald's mind an ideal of his father, the more terrible because of her own loathing for the man. She realizes her fatal mistake. Indeed, a crime on which the sacred institution is built, and for which thousands of innocent children must pay with their happiness and life, while their mothers continue to the very end without learning how hideously criminal their life is. Mrs. Alving who works herself out of to the truth; even to the height of understanding the dissolute life of the father of her child, who lives in cramped provincial surroundings, and finds no purpose in life, no outlet for his exuberance. It is through Oswald, which becomes illumed to her. Mrs. Alving struggles and suffers mightily and in her travail affirms the greatness of human spirit [13]. In this regard, Northam's comment on Mrs. Alving can be mentioned:

Mrs. Alving at last has been freed from the gloom of ignorance induced by convention. She sees with dreadful clarity the consequences of her subservience to public opinion. Her freedom is cheerless, but, she is at last aware of stark reality, even though her awareness is achieved through tragedy... Mrs. Alving imagines herself to be enlightened enough to exorcise the Ghosts of the past actions; but, she comes at length to know the complete irrevocability of deeds done long ago [12].

Mrs. Alving, like a true tragic protagonist, perceives truth at last through the irreparable wreck of her present life. As her world collapses, she becomes aware of the utter superficiality of her earlier view that she might someday live as though the past had never been. It is through her abandonment of all hopes that she comes to terms with life. When she first notices the physical change in Oswald, she shrieks, but soon she controls her shrieks and stares at the horrible scene in complete silence. She accepts the inevitable. Moreover, sexual relationship between Pastor Manders and Mrs. Alving before her marriage is also manifested through their dialogue. Mrs. Alving had a sexual relation with Pastor Manders that we can realize through their dialogue:

Mrs. Alving: Oh, how can you say that? Oswald takes after me.
Manders : Yes, but there's an expression at the corner of his mouth, something about his lips, that reminds me so vividly of Alving at any rate now then he's smoking.

Mrs. Alving: How can you say that? Oswald has much more the mouth of a clergyman, I think.

Manders: True, True. Some of my colleagues have a similar expression [7].

From their conversation, Ibsen, with his dramatic technique, wants to shed a new light over the physical attraction between Mrs. Alving and Pastor Manders in terms of their same physical appearance, especially mouth and lips of Pastor Manders and Oswald. Thus, I have tried to apply the biological theory of hereditary genetics through the character- analysis of Mrs. Alving [12].

\section{Freudian and Menckenian Views on "Hereditary Disease"}

Regarding 'Hereditary Disease,' Freud argues that congenital 'variation of the sexual constitution' upon which the greatest height falls but the existence may be easily understood and can be established through the later manifestation. The variation of the original disposition must lead to the formation of an abnormal sexual life. One calls these 'degenerative' and considers them as an expression of hereditary deterioration. In more than half of the severe cases of hysteria, compulsion neurosis etc. which Freud has treated through the psychotherapy that their fathers have gone through an attack of syphilis before marriage they have either suffered from tabs or generasis, or there is a definite history of lues. The children, who are later neurotic, show absolutely no signs of hereditary lues so that the abnormal sexual constitution can be the last off-shoot of the luetic heredity. It is from Freudian thought to put down a descent from syphilitic parents as a regular and indispensable etiological determination of the neuropathy constitution. The hereditary relation of the positive perverts is not known because they know how to evade inquiry. The perversions and psycho neurosis in the different sexes of the same family are so distributed that the male members or one of them, is a positive pervert, while the females are negative perverts or hysterics [14]. Regarding 'syphilis', H. L. Mencken's comment may be projected in this regard: a woman who continues to cohabit with a syphilitic husband may expect to have defective children; that a neurotic and lascivious woman is apt to be horrified when she finds that she is pregnant; that the world is barbarously cruel to a woman who has violated the seventh commandment or a man who has violated the Eighth [15].

Thus Freudian and Menckenian concept concerning the venereal disease can be applied in the play, Ghosts, where we see that heredity is an important issue of the same family.

'Syphilis' is a hereditary disease which stands for poison in relation to sexual life. It has had poisonous effect upon Captain Alving and Oswald. Society considers Alving as one of its pillars though he is "a dissolute," a drunkard, "a degenerated," "a libertine" and a "rakish" person. The sexual attraction of Captain Alving makes a permanent impression upon Oswald at the age of seven. In Paris, Oswald lives a bright and happy life among the comrades, but according to him that is too much for his strength, and he is incurably ruined for life by his own heedlessness. At the end of the first act scene, Oswald appears "smoking a big meerschaum pipe" [7] looking like a dead image of his father, and he makes a pass at Regina and presumably, tries to grab and 
kiss her, recreating for Mrs. Alving the ghosts [16] of the past from the "conservatory" - her husband and their maid. Thus, Ibsen shows the effect of syphilis as a hereditary disease leading to the softening of the son's brain at the age of 20 , or for the father's promiscuous living before or about the time of the child's birth is medically untenable. Ibsen's Ghosts is not only about syphilis but also about the consequences of human predicament "about the cause of some kinds of suffering, and its relationship to moral responsibility." Oswald is attacked by an ancestral curse namely syphilis. He says to his mother in accordance with his doctor's comment: "The sin of the father is visited upon the children" [7]. Both Captain Alving and Oswald have been affected by venereal disease. Consequently, both of them fall victim to tragic downfall. On the other hand, Johanna and Regina, following no other alternative way, find livelihood in prostitution. Through plotconstruction, dramatic technique, and art of characterization, my research-work draws a new light over hereditary genetics of human society.

This suggestion seems to be that Oswald is fore doomed "wormeaten" from his birth. His physical relationship with his half-sister, Regina has brought about a dreadful change not for his own tragic end but for the whole Alving Heritage. The sinful incestuous union and rakish behavior of his father has influenced Oswald to a greater extent. Ibsen's Ghosts is about human predicament which is almost archetypal namely a situation of bondage or confinement and man's struggle for freedom from hereditary guilt. Ibsen's purpose is to expose hypocrisy, stigma, false trammels, incestuous relationship between men and women, and upsetting of the apple-cart of the traditional values of the 19th century bourgeois custom and order. $\mathrm{He}$ is outraged by the hypocritical behavior of Norwegian society which has first indulged and idolized him and, then, has turned malignantly on him. He feels that such behavior deserves punishment; he knows how to inflict on the society. Ibsen also directs his attitude against the emptiness and carelessness of male members of the society.

\section{Conclusion}

In conclusion, we can assume that the issues of heredity and genetics cannot be separated in the play, Ghosts, where an incestuous relationship between master and maid-servant as well as brother and sister becomes an issue around which the clash of hereditary guilt revolves. Mrs. Alving's 'complexities' make her falter as she fights with the ghosts of hereditary disease for power and possession of her only son, Oswald and of the whole Alving Heritage. The question of hereditary guilt remains complicated as Ibsen shows that it is in the very nature of man that he cannot resolve the conflict between salvation and morality, individual sexual impulse and social responsibility. Ibsen has created a permanents impression of a middle class society upon which hereditary guilt remains unchanged. The text, Ghosts continues to evoke wider interest because the complex portrayal of the discourse of hereditary guilt remains central concerns in today's societies as well.

\section{References}

1. Walter HE (1913) Genetics-An introduction to the study of hereditary. New York: The Macmillan Company.

2. Stokes JH, Beerman H, Ingraham NR (1945) Modern Clinical Syphilology. (3rdedn) Philadelphia and London: W.B. Saunders.

3. King A, Nicol C (1975) Venereal Disease (3rdedn) London: Bailliere Tindall.

4. Hartl DL, Jones EW (1998) Genetics: Principles and Analysis (4thedn) Sudbury, Massachusetts: Jones and Bartlett Publishers, Canada.

5. Belsey Catherine (1985) The subject of tragedy: Identity and difference in renaissance drama. London: Methuen \& Co. Ltd.

6. Kemp S (1997) "Sexuality", in Feminism. Oxford and New York: Oxford University Press.

7. Kushwaha (1987) Ibsen’s Ghosts. Chennai, Kolkata, Mumbai, New Delhi: Mcmillan India Ltd.

8. Chowdhury K (2006) Ghosts in Ibsen-er Natok-O-Kobita. Selina Hosain, Dhaka: Mowla Brothers.

9. Freedman J (2002) "Sexuality and Power," Feminism. New Delhi, Mumbai, Chennai and Kolkata: Viva Books Private Ltd.

10. Moen RL (2006) "From Regina to Hild: A study in Ibsen's youngest female characters," in the living Ibsen proceedings - The 11th International Ibsen Conference, Oslo: University of Oslo Press.

11. Shaw GB (1966) The Quintessence of Ibsenism. New York: Hill and Wang, Inc.

12. Chowdhury K (1978) "Ibsen’s Ghosts: A brief critical study", The Dacca University Studies. Dacca: Dacca University.

13. Goldman E (1914) The Significance of The Modern Drama. Boston: The Gorham Press.

14. Brill AA (1963) The basic writings of sigmund freud. New York: Random House, INC.

15. Mc Farlane, James W (1962) "Revaluation of Ibsen," in discussions of Henrik Ibsen. Boston: D.C. Health and Company.

16. Rem T (2006) "Afterword to Ghosts," in said about Ibsen - by Norwegian Writers. Robert Ferguson, Oslo: Norwegian Ministry of Foreign Affairs and Gyldendal Norsk. Forlag. 